\title{
Tinjauan Akad Ijarah terhadap Wanprestasi Sewa Menyewa Indekost pada Masa Pandemi Covid-19
} \author{
Bandung, Indonesia. \\ *avrilliawulandari316@gmail.com
}

Avrillia Wulandari Putri Supriyadi*

Prodi Hukum Ekonomi Syariah, Fakultas Syariah, Universitas Islam

\begin{abstract}
Ijarah contract is a contract of transfer of usufructuary rights over an item or service through payment of rental wages, without being followed by a transfer of ownership of the goods themselves. One example of an ijarah contract is renting a boarding house, but in its implementation there are unexpected problems that result in termination or cancellation of the agreement. This study aims to find out how the ijarah contract reviews will be rented out in boarding houses in Jayaraga Village, Tarogong Kidul District, Garut Regency during the Covid 19 Pandemic.The research method used is field research with descriptive qualitative research and the sample in this study is the boarding house room located in Jayaraga Village, Tarogong Kidul District, Garut Regency. The data sources used are primary data and secondary data. Data collection techniques used are interviews, direct observation and documentation. The results of the study show that if the ijarah agreement is carried out in renting a boarding house room, it has fulfilled the pillars and conditions of the Ijarah contract, and violations that occur in the ijarah contract must be resolved by both parties without harming either party.
\end{abstract}

Keywords: Ijarah Agreement, Lease, Default, Agreement.

\begin{abstract}
Abstrak. Akad ijarah merupakan akad pemindahan hak guna atas suatu barang atau jasa melalui pembayaran upah sewa, tanpa diikuti dengan pemindahan kepemilikan atas barang itu sendiri. Salah satu contoh dari akad ijarah adalah sewa menyewa kamar indekos, akan tetapi dalam pelaksanaaannya terdapat permasalahan diluar dugaan yang mengakibatkan adanya pemutusan atau pembatalan perjanjian. Penelitian ini bertujuan untuk mengetahui bagaimana tinjauan akad ijarah terhadap akan sewa-menyewa kamar indekos di Desa Jayaraga Kecamatan Tarogong Kidul Kabupaten Garut pada saat masa Pandemi Covid 19. Metode penelitian yang digunakan adalah penelitian lapangan dengan jenis penelitian kualitatif deskriptif dan sampel dalam penelitian ini yaitu kamar Indekos yang berada di Desa Jayaraga Kecamatan Tarogong Kidul Kabupaten Garut. Sumber data yang dugunakan merupakan data primer dan data sekunder. Teknik pengumpulan data yang digunakan adalah wawancara, observasi langsung dan dokumnetasi. Hasil penelitian menunjukan jika Akad ijarah yang dilakukan dalam sewa menyewa kamar indekos sudah memenuhi rukun dan syarat Akad Ijarah, dan pelanggaran yang terjadi dalam akad ijarah harus diselesaikan oleh kedua belah pihak tanpa merugikan salah satu pihak.
\end{abstract}

Kata Kunci: Akad Ijarah, Sewa Menyewa, Wanprestasi, Perjanjian. 


\section{A. Pendahuluan}

Islam telah mengajarkan kita tentang hifzul an-nafs, yang artinya menjaga diri. Dalam kehidupan sehari-hari manusia pastilah membutuhkan tempat tinggal, terutama bagi mereka yang merantau baik dalam mencari pekerjaan maupun ilmu. Maka dengan cara mencari tempat tinggal saat menempuh ilmu ataupun pekerjaan maka hal tersebut termasuk dalam hifzul annafs. (Dianingsih, 2016)

Sebagaimana yang biasa terjadi dalam masyarakat di Desa Jayaraga, Kecamatan Tarogong Kidul, Kabupaten Garut, dalam rangka memenuhi dan menambah penghasilan mereka melakukan transaksi dalam pemanfaatan tempat tinggal sebagai usaha sewa kamar indekos. Hal ini dikarenakan latar belakang warga yang sebagian besar adalah masyarakat yang cukup mampu untuk memiliki lahan tempat tinggal yang luas, selain itu banyaknya para pendatang sangat mempengaruhi pelaksanaan kegiatan sewa menyewa ini, jumlah para pendatang yang banyak serta beraneka ragam ini menjadikan atau menimbulkan akibat dari praktik sewa-menyewa rumah kontrakan di daerah Jayaraga. Ditinjau dari segi bisnis sewamenyewa kamar kontrakan ini sangat diminati oleh warga setempat selain sebagai usaha sampingan, usaha ini juga disebut sebagai ladang bisnis yang menjanjikan karena tempat yang sangat strategis dekat dengan Perguruan Tinggi, Sekolah Menengah Atas, dan Sekolah Menengah Pertama.

Pelaksanaan akad sewa-menyewa (ijarah) indekos dilakukan antara penyewa (musta'jir) dan pemilik kamar indekos (mu'jir). Penyewa (musta'jir) melihat-lihat kamar indekos terlebih dahulu setelah itu pemilik kamar indekos memberitahu beberapa fasilitas yang tersedia ditempatnya, seperti ranjang, lemari, listrik dan air. Dengan kata lain penyewa (mu'jir) menyewa kamar indekos beserta dengan fasilitas-fasilitasnya

Seperti yang terjadi sekarang ini, adanya pandemi Covid-19 sebagai jenis penyakit menular yang menimbulkan kedaruratan untuk kesehatan seluruh masyarakat, membuat Pemerintah Indonesia menetapkan bahwa pandemi Covid-19 sebagai bencana nasional. Hal ini menimbulkan kebijakan pemerintah untuk masyarakatnya melakukan social distancing atau menjaga jarak antar sesama manusia bahkan bekerja dan belajar juga harus dilakukan dari rumah.

Akibat Covid-19 menyebabkan force majeure, yaitu debitur tidak dapat memenuhi kewajibannya untuk mencapai prestasi, karena telah terjadi peristiwa yang tidak dapat dikendalikan oleh debitur, debitur tidak dapat mempertanggungjawankan, tetapi debitur tetap beritikad baik. Hal ini tentunya akan mengakibatkan tertundanya pelaksanaan kewajiban debitur, bahkan debitur dapat dibebaskan dari biaya ganti rugi karena tidak tercapainya maksud dan tujuan perjanjian. (Muljono \& Satradina, 2020)

Namun ada beberapa fakta dilapangan yang tidak sesuai dengan teori di atas, terdapatnya seorang penyewa yang menyewa kamar kost selama satu tahun dan uang sewa sudah lunas dibayar dimuka, lalu perjanjian tersebut sudah sama-sama disetujui oleh kedua belah pihak, akan tetapi pada pelaksanaannya penyewa membatalkakan secara sepihak perjanjian tersebut hanya dalam waktu 4 bulan masa kontrak kamar kost. Tetapi pada praktiknya ada penyewa yang menuntut untuk mengembalikan sisa uang sewa yang belum ditempati.

\section{B. Metodologi Penelitian}

\section{Jenis Penelitian}

Metode penelitian yang digunakan dalam penyusunan penelitian ini yaitu menggunakan penelitian kualitatif. Penelitian kualitatif adalah penelitian yang bertujuan untuk memahami fenomena tentang apa yang dialami oleh subjek penelitian misalnya perilaku, persepsi, motivasi, tindakan, dll secara holistic, dan dengan cara mendeskripsikan dalam bentuk kata-kata dan bahasa, pada suatu konteks khusus yang alamiah dan dengan memanfaatkan berbagai metode alamiah

\section{Sumber Data}

Sumber data adalah dari mana data penelitian itu diperoleh, penelitian ini ada dua sumber data yang digunakan yaitu, sumber data primer dan sekunder. 


\section{Teknik Pengumpulan Data}

1. Wawancara adalah Teknik pengumpulan data dengan mengajukan pertanyaan langsung oleh pewawancara kepada responden, dan jawaban-jawaban responden dicatat atau direkam

2. Observasi Langsung secara umum pengertian observasi adalah menghimpun bahanbahan keterangan yang diadakan dengan pengamatan dan pencatatan secara sistematis terhadap fenomena-fenomena yang dijadikan sasaran penelitian.

3. Dokumentasi adalah catatan peristiwa penting yang sudah berlalu. Dokumen biasa berbentuk tulisan, gambar, atau karya-karya monumental dari seseorang.

\section{Hasil Penelitian dan Pembahasan}

Analisa pelaksanaan akad ijarah terhadap transaksi sewa menyewa kamar indekost di Desa Jayaraga Kecamatan Tarogong Kidul Kabupaten Garut

Akad yang telah dilakukan sudah sesuai dengan akad ijarah, dimana semuanya sudah memenuhi rukun dan syarat dari akad ijarah. Aqiq atau orang yang berakad yaitu pemilik kosan selaku mu'ajir dan penyewa kosan selaku musta'jir. Lalu adanya akad ijab qabul yang dilakukan antara pemilik dan penyewa dalam melakukan perjanjian sewa menyewa kamar indekos, adanya upah yang dikeluarkan berupa biaya sewa kamar indekost dan juga manfaat yang dapat dirasakan oleh penyewa kos yaitu berupa tempat tinggal beserta fasilitasnya.

Dalam sewa-menyewa, penyewa dan pemilik kamar kos perlu memperhatikan hak dan kewajiban antara pihak -pihak yang melakukan sewa menyewa kamar kos. Sehingga tidak terjadi kesalahpahaman ketika penyewaan kamar kos berlangsung. Hak bagi penyewa merupakan kewajiban bagi pemilik kamar kos.

Hak bagi penyewa kamar kos antara lain berupa mendapatkan fasilitas kamar beserta isinya seperti kasur, kursi, meja, lemari, wifi, listrik dan air. Penyewa berhak menggunakan fasilitas beserta isinya, mendapatkan fasilitas kenyamanan menggunakan barang sewa selama tidak menggangu penghuni kos lain watau warga setempat. Mendapatkan pelayanan apabila ada fasilitas yang rusak dan dasilitas keamanan barang selama pelaksanaan sewa kamar kos. Dan berhak tau batas waktu kapan penyewaan kamar kos.

Pada pelaksanaan sewa menyewa kamar, penyewa wajib menjaga dan memelihara fasilitas yang diperoleh selama penyewaan kamar.Selain kewajiban penyewa untuk membayar sewa kamar sesuai kesepakatan, penyewa wajib menjaga keamanan bersama dengan pemilik kost. Penduduk setempat dan penghuni berperilaku berbeda. Penghuni kost lain, patuhi peraturan yang berlaku

Kewajiban pemilik indekos selama transaksi sewa menyewa adalah menyediakan tempat tidur, kasur, lemari, meja dan kursi. Selain itu pemilik kamar indekos menyediakan penyewa berupa fasilitas lain dapur, kamar mandi dan fasilitas nyaman lainnya, serta seperti tempat parkir, dan keamanannya. dan memberitahukan batas waktu untuk menyewa kamar indekos. Sedangkan pemilik kamar kos berhak mendapatkan uang sewa kaamar kos sesuatu dengan kesepakatan, menegur atau jika terlalu parah mengeluarkan penyewa apabila membuat kegaduhan atau keributan sehingga menggagu warga setempat dan penghuni kamar kos lainnya, mengatur dan beskiap baik kepada penyewa.

\section{Analisa kondisi wanprestasi pada akad sewa menyewa indekos pada masa Pandemi Covid-} 19

Pada akad sewa menyewa di Desa Jayaraga ini pengingkaran janji yang terjadi adalah pemutusan kontrak secara sepihak dimana penghuni kos telah membayar penuh uang sewa koskosan tetapi karena adanya pandemi Covid-19 ini penghuni kos tersebut memutuskan kontraknya secara sepihak dan keluar dari kosan tersebut. Beberapa alasan yang dikemukakan oleh para Penghuni kost mengapa tidak melanjutkan sewa kamar kost dianatara lain karena para mahaiswa kembali pulang kerumahnya masing-masing. Tidak sedikit masyarakat yang kehilangan pekerjaannya karena dampak dari Pemutusan Hubungan Kerja (PHK) dan tidak sedikit pula masyarakat yang usahanya mengalami gulung tikar karena dampak dari kebijakan social distancing yang diterapkan oleh pemerintah 
Keadaan yang terjadi karena adanya pandemi Covid-19 ini menyebabkan terjadinya suatu wanprestasi dimana salah seorang yang berakad atau bertransaksi tidak dapat menjalankan kewajibannya berupa prestasi dari apa yang telah disepakati antara pihak yang bersangkutan. Tetapi suatu prestasi akan dikatakan wanprestasi dikarenakan ada faktornya, salah satu faktor penyebab wanprestasi adalah keadaan memaksa diluar kemampuan debitur/debitur tidak bersalah.

Keadaan memaksa (Overmacht/Force Meajure) ialah keadaan tidak dipenuhinya prestasi oleh pihak debitur karena terjadi suatu peristiwa bukan karena kesalahannya. Peristiwa ini tidak dapat diketahui atau tidak dapat diduga akan terjadi pada waktu pembuatan perikatan. Salah satuhnya seperti adanya pandemi Covid-19 yang datang atau terjadi diluar dugaan kedua belah pihak. Hal ini akhirnya membuat debitur tidak dapat melakukan kewajibannya untuk melaksanakan prestasi tersebut. Maka dengan adanya Pandemi Covid-19 ini para penghuni kamar indekos tidak dapat melanjutkan prestasinya dalam menyewa kamar kos.

Dari pemaparan diatas maka adanya pembatalan secara sepihak yang dilakukan oleh penyewa kamar indekos termasuk dalam wanprestasi yang diakibatkan karena keadaan memaksa (force meajure) yang terjadi diluar dugaan, suatu peristiwa atau keadaan dapat dikatakan keadaan force majeure apabila memenuhi unsur-unsur yang harus dibuktikan keberadaannya yaitu: (Muljono \& Satradina, 2020)

1. Tidak terdapat unsur kelalaian atau kesengajaan untuk tidak melakukan kewajibannya.

2. Terjadinya suatu peristiwa yang tak terduga yang menyebabkan pihak tidak dapat memenuhi kewajibannya.

3. Peristiwa tersebut tidak dapat dimintakan pertanggungjawaban oleh pihak yang tidak dapat memenuhi kewajibannya.

4. Masih terdapat itikad baik dari pihak yang tidak memenuhi kewajibannya.

Akibat yang terjadi dari Covid-19 ini menimbulkan Force majeure dimana seorang debitur tidak dapat melaksanakan kewajibannya untuk mememuhi prestasinya, karena memang terjadi peristiwa diluar kendali debitur dan tidak dapat dipertanggungjawabkan oleh debitur sementara debitur tetap dalam beritikad baik. Hal ini tentu akan menyebabkan pemenuhan kewajiban oleh debitur akan tertunda, bahkan dapat juga debitur terbebas dari biaya ganti rugi akibat tidak dapat terlaksananya maksud dan tujuan perjanjian tersebut. Karena force majeure ini muncul dikarenakan peristiwa pandemi Covid-19 yang membuat perekonomian debitur tidak terpenuhi seperti sebelumnya. (Muljono \& Satradina, 2020)

Menghidari adanya pembatalan dan pemutusan perjanjian secara sepihak tersebut, para pemilik kamar indekos di Desa Jayaraga Kecamatan Tarogong Kidul Kabupaten Garut membuat aturan yang baru pada saat Pandemi Covid 19 ini untuk meminimalisir terjadinya pemutusan atau pembatalan perjanjian secara sepihak.

\section{Analisa pandangan akad ijarah terhadap penyelesaian transaksi wanprestasi sewa menyewa kamar indekos}

Permasalahan atau pelanggaran perjanjian sewa menyewa merupakan suatu hal yang pasti akan pernah terjadi, dalam penyelesaiannya sendiri pembuktian adalah salah satu hal penting untuk membantu para pihak agar menyadari kesalahan yang disegaja atau tidak disengaja.

Dalam Akad Ijarah telah dijelaskan Ijarah akan menjadi batal jika terjadi cacat pada barang sewaan karena kesalahan penyewa, rusaknya barang yang disewakan, hilangnya tujuan yang diinginkan dari ijarah, telah terpenuhinya manfaat yang diakadkan dan adanya udzur yaitu halangan sehingga perjanjian tidak memungkinkan dapat terlaksanakan sebagaimana mestinya. yaitu seperti:

Pelanggaran yang terjadi pada akad sewa menyewa kamar indekos di Desa Jayaraga

1. Telat membayar uang sewa kamar indekos.

2. Pembatalan kontrak/Pemutusan perjanjian secara sepihak.

Permasalahan pembatalan/pemutusan perjanjian secara sepihak ini terjadi karena adanya udzur yaitu adanya suatu halangan sehingga perjanjian tidak mungkin dapat terlaksanakan sebagaimana mestinya. Salah satunya karena adanya faktor kejadian luar biasa seperti musibah, semisal karena adanya wabah penyakit seperti virus Covid-19 yang menyebabkan para penghuni tidak dapat melakukan kegiatan seperti biasanya dan memilih 
untuk kembali kerumah masing-masing dan meninggalkan kos mereka.

Penyelesaian yang dilakukan untuk menyelesaikan permasalahan ini dapat lakukan dengan cara perdamamaian (Ash-Shulhu) yaitu suatu jenis akad atau perjanjian mengakhiri perselisihan atau pertengkaran antara kedua belah pihak yang bersengketa secara damai. (Manan, 2021) Rukun yang harus terpenuhi untuk mengakhiri perselisihan ini yaitu adanya Ijab, adanya Qabul dan adanya Lafad. Jika ketiga rukun tersebut sudah terpenuhi, maka perjanjian perdamaian telah berlangsung sebagaimana yang diharapkan. (Suhrawandi, 2000)

Cara lain untuk menyelesaikan permasalahan tersebut yaitu dengan cara Tahkim atau Arbitrase yaitu pemutusan suatu persengketaan oleh seseorang atau beberapa orang yang ditunjuk oleh pihak-pihak yang bersengketa diluar hakim atau pengadilan. (Manan, 2021)

Para pemilik indekos di Desa Jayaraga kebanyakan menyelesaikannya dengan cara perdamaian (Ash-Shulhu) dengan bermusyawarah agar tidak terjadi kerugian salah satu pihak. Tetapi ada juga pemilik indekos yang menyelesaikannya dengan cara tahkim atau arbitrase dimana ketua RT atau RW adalah seseorang yang ditunjuk sebagai penengah dalam penyelesaian permasalahan tersebut.

Solusi lain yang dibuat oleh para pemilik indekos di Desa jayaraga juga membuat peraturan baru dengan memberi tahu terlebih dahulu sebelum terjadinya pelaksanaan akad sewa menyewa yaitu mengembalikan uang sewa setengahnya atau tidak mengembalikan uang sewa sama sekali sesuai dengan keadaan terjadinya pembatalan/pemutusan perjanjian.

Dari pemaparan diatas analisa akad ijarah terhadap penyelesaian wanprestasi sewa menyewa kamar indekos terletak karena adanya udzur yaitu suatu halangan sehingga perjanjian tidak mungkin dapat terlaksanakan sebagaimana mestinya. (Lubis, Pasaribu, \& Chairuman, 2004) Hal tersebut yang menyebabkan telatnya pemabayaran uang sewa dan pembatalan atau pemutusan perjanjian secara sepihak yang diakibatkan karena keadaan tidak terduga seperti adanya Pandemi Covid-19 ini..

\section{Kesimpulan}

Berdasarkan pembahasan dalam penelitian ini, peneliti menyimpulkan beberapa hasil penelitian sebagai berikut:

1. Akad Ijarah terhadap transaksi sewa menyewa kamar indekos di Desa Jayaraga Kecamatan Tarogong Kidul Kabupaten Garut telah dilakukan sudah sesuai dengan akad ijarah, dimana semuanya sudah memenuhi rukun dan syarat akad ijarah. Aqid atau orang yang berakad yaitu pemilik kosan selaku mu'ajir dan penyewa kosan selaku musta'jir. Selain itu terdapat akad ijab qabul yang dilakukan antara pemilik dan penyewa dalam melakukan perjanjian sewa menyewa kamar indekos, dan adanya upah yang dikeluarkan berupa biaya sewa kamar indekost dan serta manfaat yang dapat dirasakan oleh penyewa kos yaitu berupa tempat tinggal beserta fasilitasnya.

2. Kondisi wanprestasi pada akad sewa menyewa indekos pada masa pandemi covid-19 di Desa Jayaraga Kecamatan Tarogong Kidul Kabupaten Garut adalah karena keadaan memaksa (force meajure) yang terjadi diluar dugaan. Pembatalan secara sepihak yang dilakukan oleh penyewa kamar indekos termasuk dalam wanprestasi yang diakibatkan karena keadaan memaksa yang terjadi diluar dugaan. Penyelesaikan permasalahan tersebut harus diselesaikan antara kedua belah pihak agar menghasilkan kesepakatan tanpa merugikan salah satu pihak. Agar terhindar dari hal tersebut para pemilik kamar indekos di Desa Jayaraga Kecamatan Tarogong Kidul Kabupaten Garut membuat aturan yang baru pada saat Pandemi Covid 19 ini untuk meminimalisir terjadinya pemutusan atau pembatalan perjanjian secara sepihak.

3. Pandangan akad ijarah terhadap transaksi wanprestasi pada sewa menyewa kamar indekos yaitu adanya keterlambatan dalam pembayaran uang sewa dan pembatalan perjanjian secara sepihak akibat pandemi Covid-19. Dari pemaparan diatas analisa akad ijarah terhadap penyelesaian wanprestasi sewa menyewa kamar indekos terletak karena adanya udzur yaitu suatu halangan sehingga perjanjian tidak mungkin dapat terlaksanakan sebagaimana mestinya. Hal tersebut yang menyebabkan telatnya pemabayaran uang sewa dan pembatalan atau pemutusan perjanjian secara sepihak yang 
diakibatkan karena keadaan tidak terduga seperti adanya Pandemi Covid-19 ini. Maka menurut akad ijarah penyelesaian permasalahan dapat diselesaikan dengan cara perdamaian (Ash-Shulhu) atau tahkim (Arbitrase) untuk menghasilkan kesepakatan tanpa merugikan salah satu pihak.

\section{Acknowledge}

Segala puji bagi Allah SWT penulis panjatkan, karena berkat Rahmat dan Hidayah-Nya penulis dapat menyelesaikan juena ini dengan tepat waktu. Tidak lupa shalawat serta salam penulis limpahkan kepada junjunan kita Nabi Muhammad SAW yang membawa umatnya dari zaman kegelapan ke zaman yang terang benderang.

Akhirnya, penulis dapat menyelesaikan jurnal dengan judul "Tinjauan Akad Ijarah Terhadap Wanprestasi Sewa Menyewa Indekost Pada Masa Pandemi Covid-19 (Studi Kasus Desa Jayaraga Kecamatan Tarogong Kidul Kabupaten Garut)"

Merupakan suatu kehormatan bagi penulis untuk mempersembahkan yang terbaik kepada orang sekitar penulis, yaitu kepada kedua orang tua, keluarga besar penulis, pihak civitas akademika dan pihak-pihak lain yang telah ikut andil dalam penyelesaian jurnal ini.

\section{Daftar Pustaka}

[1] Astika Nur Dianingsih, Tinjauan Hukum Islam Terhadap Akad Sewa Menyewa (Ijarah) Kamar Indekos (Purwekerto: Institut Agama Islam Negeri, 2016)

[2] Jurnal Humaniora, Keabsahan Force Meajure Dalam Perjanjian di Masa Era Pandemi Covid19, Vol.4, No. 2, Oktober 2020: 256-263 http://jurnal.abulyatama.ac.id/humaniora (diakses pada 20 februari 2021)

[3] Munjid Filughah wal A“lam, Beirut: Dār el-Machreq Sarl Publisher, 1986, h. 4

[4] Pusat Bahasa Departemen Pendidikan Nasional, Kamus Besar Bahasa Indonesia, Jakarta: Balai Pustaka, 2005, Edisi-3, h. 1057.

[5] Niniek Suparni, Kitab Undang-Undang Hukum Perdata (KUH PERDATA), Jakarta: PT Rineka Cipta, 2013, Cet-8, h. 373.

[6] Q.S Al-Baqarah (2) 233

[7] Lubis, Suhrawardi K. Pasaribu, Chairuman. 2004. Hukum Perjanjian dalam Islam. Jakarta: Sinar Grafika.

[8] Yahman, Karakteristik Wanprestasi dan Tindak Pidana Penipuan Yang Lahir dari Hubungan Kontraktual, (PRENADAMEDIA GROUP: 2014), h. 81-82

[9] Jurnal Humaniora, Keabsahan Force Majeure Dalam Perjanjian Di Masa Era Pandemi Covid-19 Vol.4, No. 2, Oktober 2020 : 256-263 http://jurnal.abulyatama.ac.id/humaniora

[10] Abdul Manan, Hukum Ekonomi Syariah: Dalam Perspektif Kewenangan Peradilan Agama. (Jakarta: Kencana, 2021). Cet I. Hlm 427.

[11] Suhrawandi, Hukum Ekonomi (Jakarta: Sinar Grafika, 2000)

[12] Abdul Manan, Hukum Ekonomi Syariah: Dalam Perspektif Kewenangan Peradilan Agama. (Jakarta: Kencana, 2021). Cet I. Hlm 427.

[13] Lubis, Suhrawardi K. Pasaribu, Chairuman. 2004. Hukum Perjanjian dalam Islam (Jakata: Sinar Grafika) 